Aoyagi, T. \& Mizuno, D. (1959). J. gen. Microbiol. 20, 173-179

\title{
Gultivation of Mycobacteria Rocked in Non-Protein Medium Containing a High Concentration of Tween 80
}

\author{
By T. AOYAGI AND D. MIZUNO \\ National Institute of Health, Tokyo, Japan
}

SUMMARY: Mycobacteria were grown in rocked $\perp$ tubes (Monod) in a medium which contained asparagine, glycerol, $1.0 \%(w / v)$ Tween 80 and no albumin fraction V. This permitted abundant well-dispersed diffuse growth. The amount of growth could be measured photometrically.

Smith (1947) reported turbidimetric observation of the growth of mycobacteria by using the medium devised by Dubos \& Davis (1946) and Dubos \& Middlebrook (1947) which contained Tween 80 and albumin fraction $V$ in a modified Kirchner's medium and allowed a diffuse growth of the organism. Volk \& Myrvik (1953), Halpern \& Kirchheimer (1954) and Miller \& Roessler (1956), reporting similar submerged cultures of mycobacteria either by aeration or by agitation, observed the logarithmic growth of the bacilli and obtained a good yield of organisms. However, all these media except that of Miller \& Roessler (1956) contained albumin fraction V.

A $\perp$-shaped culture tube devised by Monod (see Monod, Cohen-Bazire \& Cohn, 1951; van Heyningen \& Gladstone, 1953) was modified by us giving good results for rocked cultures of bacteria (Matsumura, Aoyagi \& Mizuno, 1956); the mechanical damage of bacteria was very small at good rates of oxygen diffusion into the medium. The present paper deals with the diffuse growth of various strains of mycobacteria in a defined medium containing a high concentration of Tween 80 but without albumin fraction $\mathrm{V}$, by cultivation in rocked $\perp$ tubes. The requirements for nitrogen and carbon sources were examined for these strains. A preliminary account of some of the work has already been published in Japanese (Aoyagi \& Mizuno, 1956).

\section{METHODS}

Organisms. Mycobacterium tuberculosis strains $\mathrm{H} 37 \mathrm{Rv}, \mathrm{H2}$, Imamura (avirulent human type); BCG; M. avium A-62; M. phlei; M. smegmatis were used (all these strains were supplied by the Department of Tuberculosis of this Institute).

Media. The liquid medium, a modified Sauton medium, used in these experiments had the following composition ( $\mathrm{g}$.): asparagine, $4 \cdot 0$ or sodium glutamate, 4.0 ; citric acid, $2.0 ; \mathrm{K}_{2} \mathrm{HPO}_{4}, 0.5 ; \mathrm{MgSO}_{4} .7 \mathrm{H}_{2} \mathrm{O}, 0.5$; ferric ammonium citrate, 0.05 ; glycerol, $60 \mathrm{ml}$. or glucose, 20 . These materials were dissolved in $980 \mathrm{ml}$. distilled water, adjusted to $\mathrm{pH} \mathbf{7 \cdot 2}$ and autoclaved. When glucose was used it was dissolved separately in distilled water $(20 \mathrm{~g} . / 50 \mathrm{ml}$.) steamed 3 times 
at $100^{\circ}$, and $50 \mathrm{ml}$. solution added to the previously sterilized solution of the other components made up in $930 \mathrm{ml}$. distilled water.

The above medium in $9 \cdot 8 \mathrm{ml}$. volumes was distributed into $\perp$ tubes and to each was added $0 \cdot 2 \mathrm{ml}$. of Tween 80 solution. Four mixtures were examined as nitrogen and carbon sources: asparagine + glycerol, asparagine + glucose, glutamate + glycerol, and glutamate + glucose.

Tween 80. The preparation Tween 80 of the Atlas Powder Co. was used. There was $0.55 \%$ free acid (as oleic acid) in the sample of Tween 80 used.

Culture tube. The $\perp$ tube used was $26 \mathrm{~cm}$. long and of $1.8 \mathrm{~cm}$. external diameter; the inlet side arm was $4 \mathrm{~cm}$. (ext. diam. $1.8 \mathrm{~cm}$.). The tubes were rocked 30 times/min. in a water bath at $37^{\circ}$.

Estimation of bacterial growth. The amount of growth was estimated by using a Coleman Junior photometer, setting the base of the $\perp$ vertically in it; the optical density (OD) observed at $500 \mathrm{~m} \mu$. The relationship between turbidity (OD units) and dry weight, nitrogen content of bacteria, or number of viable units/unit volume of culture under a standard condition was determined and calibration curves were constructed. The standard conditions were for bacilli grown on asparagine + glycerol medium and harvested during the logarithmic growth phase.

Inoculum and incubation. Test strains grown on Ogawa's medium (wholeegg medium) were inoculated into a modified Sauton medium (in the case of $\mathrm{BCG}$, Imamura, $\mathrm{H} 2$ and $\mathrm{H3} 7 \mathrm{Rv}$ strains passage on potato medium was done before inoculation), subcultured three times as surface cultures in the same medium and the bacterial mass actively growing in thin layers was then harvested for the test inoculum. A homogeneous suspension was made by grinding the bacterial mass with crystal balls $(7 \mathrm{~mm}$. diam.) in distilled water containing $0.5 \%(\mathrm{w} / \mathrm{v})$ Tween 80 , diluted with distilled water to the required concentration; $0.5 \mathrm{ml}$. of this suspension was inoculated into $10 \mathrm{ml}$. liquid test medium to give a final bacterial concentration equivalent to $0 \cdot 3-0.5 \mathrm{mg}$. dry weight organism $/ 10 \mathrm{ml}$. The medium for the three successive surface subcultures before harvesting for inoculum was the same as that to be used for the test medium, but in the case of poor growth in these subcultures the standard medium (asparagine + glycerol) was used, when the possible carryover of nutrients from subcultures could not be avoided.

\section{RESULTS}

\section{Determination of optimal concentration of Treen 80}

The concentrations of Tween 80 examined were $0.05,0 \cdot 1,0.3,0.5,0.7,1.0$, $2 \cdot 0,3 \cdot 0 \%(w / v)$. With the medium containing asparagine + glycerol every strain grew more luxuriantly the greater the concentration of Tween 80 up to $1.0 \%(w / v)$ when using inocula prepared as described above (Fig. 1). No differences were observed between 1 and $3 \%$ of Tween 80 . When sodium glutamate was used as nitrogen source, the optimal concentration of Tween 80 was $0.7-1.0 \%(w / v)$. All the strains tested in this experiment showed similar results. 


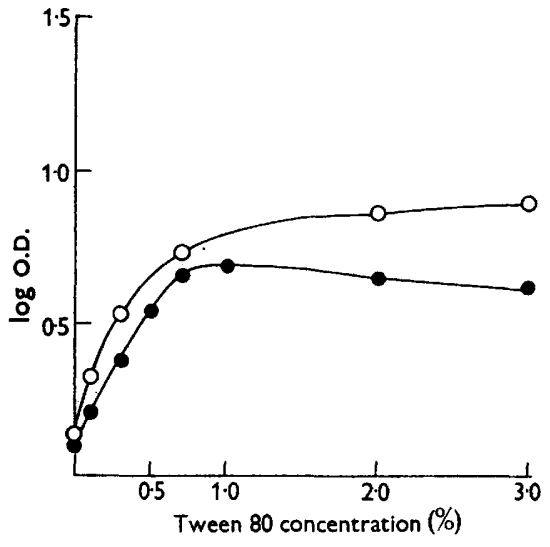

Fig. 1

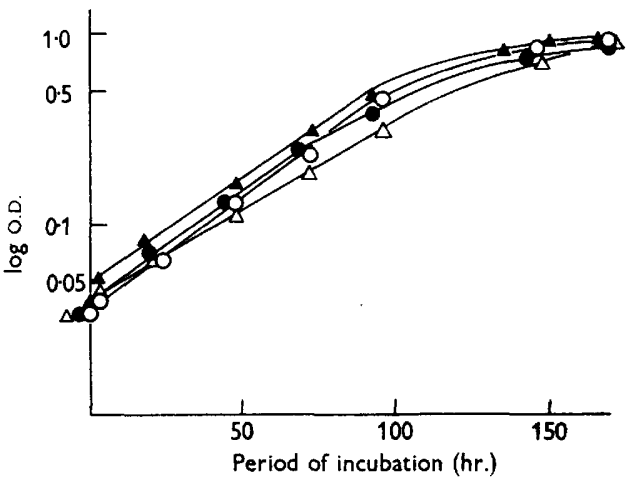

Fig. 2

Fig. 1. The relationship between the concentration of Tween 80 and the maximum growth of the organisms. $\mathrm{O}-\mathrm{O}$, asparagine + glycerol ; - - , glutamate + glycerol. The organism used was Mycobacterium avium (A-62); measured at $22 \mathrm{hr}$.

Fig. 2. The growth curve of various strains of mycobacteria. $\bigcirc-O$, strain H37 Rv; -0 , strain H2; $\triangle-\triangle$, strain Imamura; $\Delta-\Delta$, strain BCG.

Growth curve of mycobacteria grown in rocked $\perp$ tubes with different nitrogen and carbon sources

Typical examples of the growth curve are shown in Figs. 2 and 3. The generation time of each strain is shown in Tables 1 and 2, which give the results with glycerol or glucose as carbon source. Each figure is the arithmetic mean of more than two experiments. As shown in Tables 1 and 2, asparagine and glucose were the preferred nitrogen and carbon sources, respectively. With

Table 1. The generation time of various mycobacteria in rocked culture using glucose as a carbon source

\begin{tabular}{|c|c|c|c|c|}
\hline \multirow[b]{3}{*}{ Strain } & \multicolumn{4}{|c|}{ Nitrogen source } \\
\hline & \multicolumn{2}{|c|}{ Asparagine } & \multicolumn{2}{|c|}{ Glutamate } \\
\hline & $\begin{array}{l}\text { Pre-incubation } \\
\text { medium }\end{array}$ & $\begin{array}{r}\text { Generation } \\
\text { time (hr.) }\end{array}$ & $\begin{array}{l}\text { Pre-incubation } \\
\text { medium }\end{array}$ & $\begin{array}{c}\text { Generation } \\
\text { time (hr.) }\end{array}$ \\
\hline H37 Rv & $\begin{array}{l}\text { Asp + gly } \\
\text { Asp + gluc } \\
\text { Glut + gluc }\end{array}$ & $\begin{array}{l}28 \\
16 \\
18\end{array}$ & $\begin{array}{l}\text { Asp + gly } \\
\text { Asp + gluc } \\
\text { Glut + glue }\end{array}$ & $\begin{array}{l}28 \\
18 \\
20\end{array}$ \\
\hline H2 & $\begin{array}{l}\text { Asp + gly } \\
\text { Asp + gluc } \\
\text { Glut + glue }\end{array}$ & $\begin{array}{l}20 \\
22 \\
37\end{array}$ & $\begin{array}{l}\text { Asp + gluc } \\
\text { Glut + gluc }\end{array}$ & $\begin{array}{l}22 \\
37\end{array}$ \\
\hline Imamura & $\begin{array}{l}\text { Asp }+ \text { gly } \\
\text { Asp + glue }\end{array}$ & $\begin{array}{l}30 \\
22\end{array}$ & $\begin{array}{l}\text { Asp + gly } \\
\text { Asp + gluc }\end{array}$ & $\begin{array}{r}\infty \\
>50\end{array}$ \\
\hline BCG & Glut + gluc & 25 & Glut + gluc & 24 \\
\hline M. avium $(\mathrm{A}-62)$ & Asp + glue & 4 & Asp + gluc & 8 \\
\hline M. smegmatis & Asp + gly & 3 & & \\
\hline
\end{tabular}

Asp $=$ asparagine $;$ glut $=$ sodium glutamate $;$ gly $=$ glycerol $;$ gluc $=$ glucose. 
Table 2. The generation time of various mycobacteria in rocked culture using glycerol as a carbon source

\begin{tabular}{|c|c|c|c|c|}
\hline \multirow[b]{3}{*}{ Strain } & \multicolumn{4}{|c|}{ Nitrogen source } \\
\hline & \multicolumn{2}{|c|}{ Asparagine } & \multicolumn{2}{|c|}{ Glutamate } \\
\hline & $\begin{array}{c}\text { Pre-incubation } \\
\text { medium }\end{array}$ & $\begin{array}{l}\text { Generation } \\
\text { time (hr.) }\end{array}$ & $\begin{array}{c}\text { Pre-incubation } \\
\text { medium }\end{array}$ & $\begin{array}{c}\text { Generation } \\
\text { time (hr.) }\end{array}$ \\
\hline H37 Rv & $\begin{array}{l}\text { Asp }+ \text { gly } \\
\text { Asp }+ \text { gluc } \\
\text { Glut + gluc }\end{array}$ & $\begin{array}{l}28 \\
20 \\
28\end{array}$ & $\begin{array}{l}\text { Asp + gly } \\
\text { Glut + gluc }\end{array}$ & $\overline{28}$ \\
\hline H2 & $\begin{array}{l}\text { Asp + gly } \\
\text { Asp + gluc }\end{array}$ & $\begin{array}{l}25 \\
27\end{array}$ & $\begin{array}{l}\text { Asp + gly } \\
\text { Asp + gluc }\end{array}$ & $\begin{array}{l}35 \\
30\end{array}$ \\
\hline Imamura & $\begin{array}{l}\text { Asp + gly } \\
\text { Asp + gluc }\end{array}$ & $\begin{array}{l}22 \\
20\end{array}$ & Asp+glue & 22 \\
\hline BCG & Asp + gly & 28 & - & - \\
\hline M. avium (A-62) & Asp + gly & 5 & Glut + gly & 25 \\
\hline M. phlei & Asp + gly & 4 & Glut + gly & 10 \\
\hline M. smegmatis & Asp + gly & $\mathbf{3}$ & Glut + gly & $\mathbf{3}$ \\
\hline
\end{tabular}

Asp = asparagine; glut $=$ glutamate $;$ gly $=$ glycerol; gluc $=$ glucose.

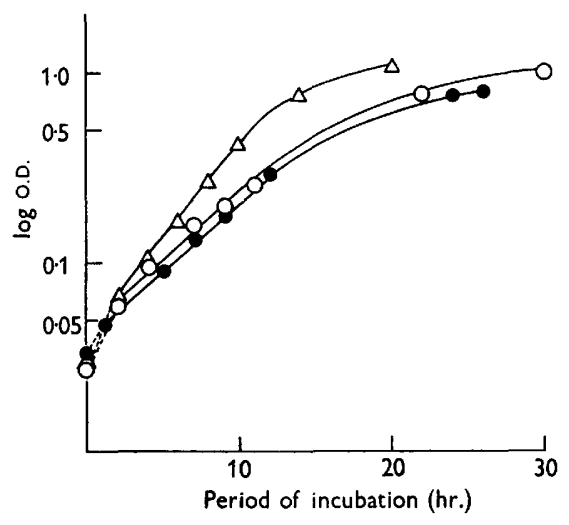

Fig. 3

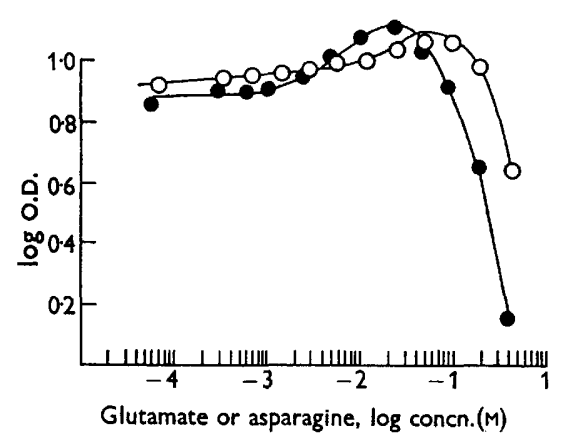

Fig. 4

Fig. 3. The growth curve of various strains of mycobacteria. $\mathrm{O}-\mathrm{O}$, Mycobacterium avium (A-62); - - M. phlei; $\triangle-\triangle$, M. smegmatis.

Fig. 4. The relationship between the concentration of glutamate and of asparagine and the growth of strain Imamura at $100 \mathrm{hr}$. The carbon source was glucose. $\bigcirc-\bigcirc$, asparagine; - glutamate.

the BCG strain glutamate + glycerol and asparagine + glucose did not give good growth on the surface subcultures for inoculum and only glutamate + glucose and asparagine + glycerol showed good growth in the test-rocked cultures.

The effect of different concentrations of asparagine and of sodium glutamate in the presence of glucose is shown in Fig. 4 and of glycerol and glucose in the presence of asparagine in Fig. 5 for the Imamura strain. Similar relations were observed with the other strains. The relationship between the total 
viable units and optical density during growth is shown in a typical case (Fig. 6).

Subcultures. Every strain examined could be subcultured serially more than three times by using as inoculum $0.5 \mathrm{ml}$. of culture in the logarithmic phase. In the case of the Imamura strain (avirulent human type) and Mycobacterium smegmatis more than 25 serial subcultures were carried out in the asparagine + glucose medium. No loss of acid fastness with the Imamura strain was

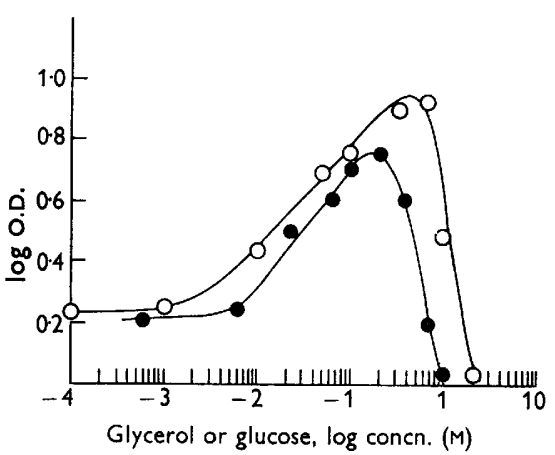

Fig. 5

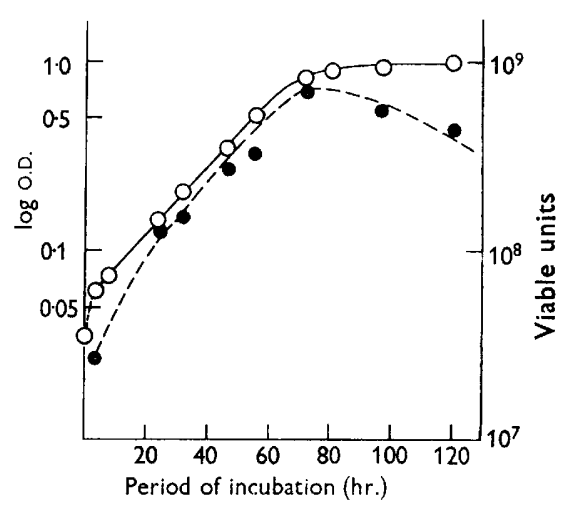

Fig. 6

Fig. 5. The relationship between the concentration of glucose and of glycerol and the growth of strain Imamura at $100 \mathrm{hr}$. The nitrogen source was asparagine. $\mathrm{O}-\mathrm{O}$, glycerol; -1 , glucose.

Fig. 6. The growth curve of viable units and of optical density. Imamura strain was used. $\mathrm{O}-\mathrm{O}$, optical density; $-\mathrm{O}$, viable units.

observed after 10 serial subcultures, but a slight decrease was observed after 20 subcultures; $M$. smegmatis showed marked decrease of acid fastness after 10 subcultures. No significant differences of generation time or of growth curve were observed all through the subcultures both for Imamura and $\boldsymbol{M}$. smegmatis. Electron microscopy showed no differences from the original form when organisms of the Imamura strain were observed at the 10th and 25th serial subcultures.

\section{DISCUSSION}

Media for submerged diffuse culture of mycobacteria have till now contained albumin fraction $\mathrm{V}$ to antagonize the toxic effect of free oleic acid possibly contained in Tween 80, especially when using very small inocula. Bloch \& Noll (1953) observed the loss of acid fastness of strain $\mathrm{H37} \mathrm{Rv}$ in cultures containing high concentrations of Tween 80 . Minami (1957) showed a morphological change of Mycobacterium avium (Takeo strain) in the presence of oleic acid $\left(10^{-3} \mathrm{M}\right)$. In the present work Tween 80 at the concentration of $0 \cdot 7-1.0 \%(\mathrm{w} / \mathrm{v})$ (equiv. $10^{-4} \mathrm{M}$ free oleic acid in our preparation) did not show the above toxicity nor morphological changes. This was probably partly due to the size of our inoculum (Davis, 1948), which could annul the toxic effect of oleic acid, and also to the annulling effect of high concentrations of 
Tween 80 against oleic acid toxicity (Davis \& Dubos, 1947; Camien \& Dunn, 1957; Minami, 1957). The viable count during growth showed no significant drop, at least not during the exponential phase.

That we could measure the degree of bacterial growth with a conventional photometer by placing the $\perp$ tube directly in it at any time enabled us to estimate generation time very rapidly; this has hitherto been difficult to estimate easily (e.g. Youmans, 1946; Youmans \& Youmans, 1949; Volk \& Myrvik, 1953; Halpern \& Kirchheimer, 1954).

Kull \& Grimm (1952) reported that the growth of Mycobacterium tuberculosis was inhibited by agitation or by aeration in submerged cultures. We had evidence that vigorous agitation and aeration can damage bacteria (Staphylococcus aureus) mechanically especially in the early phase of the growth (Matsumura et al. 1956). The present work with $\perp$ tubes used a mild rocking motion and gave sufficient aeration for luxuriant growth. When we used the medium of Dubos in $\perp$ tubes white precipitates, possibly denatured albumin, sometimes appeared and interfered with the observation of optical density. For this reason a non-protein medium is desirable for rocked cultures. Under the conditions used the best carbon and nitrogen sources as regards growth rate were asparagine + glucose and the best as regards final yield of bacteria were asparagine + glycerol. The relatively heavy inocula used with these media made it difficult to determine the lag period of the growth curve, because of the period during the early stages of incubation (several hours, depending on the strain) while the bacterial suspension of the inoculum was becoming uniformly dispersed. To the naked eye the bacterial suspension appeared uniform but staining showed groups of 2 or 3 to more than 20 bacteria, while about one third of the organisms were always found separated from each other. Tween 80, among other surface-active agents examined (including Triton WR-1339) had the best homogenizing effect.

The advice of Dr T. Hashimoto is gratefully acknowledged.

The authors are indebted to Professor B. C. J. G. Knight for revising the manuscript.

\section{REFERENCES}

Aoyagi, T. \& Mizuno, D. (1956). A shake culture of acid-fast bacteria. Proc. Jap. Bact. Soc. In Jap. J. Bact. 11, 629.

BLOCH, H. \& NolL, H. (1953). Studies on the virulence of tubercle bacilli variation in virulence effect by Tween 80 and thiosemicarbazone. J. exp. Med. 97, 1.

Camien, M. N. \& DunN, M. S. (1957). Saturated fatty acids as bacterial antimetabolites. Arch. Biochem. Biophys. 70, 327.

Davis, B. D. (1948). Absorption of bacteriostatic quantities of fatty acids from media by large inocula of tubercle bacilli. Publ. Hlth Rep. Wash. 63, 455.

DAvis, B. D. \& Dubos, R. J. (1947). The binding of fatty acids by serum albumin, a protective growth factor in bacteriological media. J. exp. Med. 86, 215.

Dubos, R. J. \& Davis, B. D. (1946). Factors affecting the growth of tubercle bacilli in liquid media. J. exp. Med. 83, 409.

Dubos, R. J. \& Middlebrook, G. (1947). Media for tubercle bacilli. Amer. Rev. Tuberc. 56, 334. 
HALPERN, B. \& KirChHEIMER, W. F. (1954). Studies on the growth of Mycobacteria. II. The effect of oxygenation and aeration on the growth pattern of Mycobacteria. Amer. Rev. Tuberc. 70, 665.

Heyningen, W. E. van \& Gladstone, S. P. (1953). The neurotoxin of Shigella shigae. 3. The effect of iron on production of the toxin. Brit. J. exp. Path. 34, 221.

KuLl, F. C. \& GRIMM, M. R. (1952). Growth of Mycobacterium tuberculosis var. hominis in agitated culture. J. Bact. 64, 431.

Matsumura, G. Aoyagi, T. \& Mizuno, D. (1956). Shaken culture by Monod type. Kagaku-no-Ryoiki (J. Jap. Chem.), 10, 65.

MrLler, I. L. \& Roessler, W. G. (1956). Growth of Mycobacterium tuberculosis in liquid media. Amer. Rev. Tuberc. 73, 716.

Mrnami, K. (1957). Bactericidal action of oleic acid for tubercle bacilli. II. Morphological response. J. Bact. 73, 345.

Monod, J., Cohen-Bazire, G. \& CoHn, M. (1951). Sur la biosynthèse de la $\beta$-galactosidase (lactase) chez Escherichia coli, la specificité de l'induction. Biochem. Biophys. Acta, 7, 585.

Sмiтн, D. G. (1947). Quantitative measurement of growth of Mycobacterium tuberculosis. Effect of streptomycin. Proc. Soc. exp. Biol., N.Y. 64, 36.

Volk, W. A. \& MYrVIK, Q. N. (1953). An explanation for the arithmetic linear growth of mycobacteria. J. Bact. 66, 386.

Youmans, G. P. (1946). A method for the determination of culture cycle and the growth rate of virulent human type tubercle bacilli. J. Bact. 51, 703.

Youmans, G. P. \& Youmans, A. S. (1949). A method for the determination of the rate of growth of tubercle bacilli by the use of small inocula. J. Bact. 58, 247 .

(Received 3 July 1958) 